\title{
1 Human, Urban and Environmental-Induced \\ 2 Alterations in Mangroves Pattern along Arabian Gulf 3 Coast, Eastern Province, KSA
}

\author{
`Sameh A. Amin; 'Mai S. Fouad; ‘Wafaa A. Altaisan \& *Mohammad A. Zyada \\ - Department of Biology, Faculty of Science, University of Dammam, K.S.A. \\ - Department of Botany, Faculty of Science, University of Fayoum, Egypt. \\ *Department of Biology, Faculty of Science, University of Damietta, Egypt.
}

Abstract: Significant changes have occurred at Arabian Gulf Coast of Saudi Arabia over the last three decades. The area of mangrove was reduced by about $55 \%$. Thus the economic, social, and environmental value of mangroves must be assessed over short -to long-term scales and employ these assessments for the awareness rising at local communities. This study provides a preliminary assessment of the risks on mangrove vegetation; it will provide database to mitigate the tremendous pressures due to coastal development and urban activities. The effects of human development on the mangrove plant cover in Eastern Region of KSA were recognised, during 2013 to 2016. The mean variations of physio-chemical characteristics in water and sediment were recorded. With regard to water analyses including; nitrogen, phosphorus, TSS, TDS, BOD, and turbidity were evaluated. On the other hand, for sediment: TDS, nitrogen, phosphorus, sulphate and total organic carbon were assessed. Moreover, the growth parameters: plant height, and size index, of Avicennia marina were recorded and estimated. It is concluded that human impact and urban developments have exerted drastic effects on the coastal ecosystems and its environments.

Key Words: Mangrove; Avicennia marina; Size Index; Sediment; Urban Development; Human Impacts.

\section{Introduction}

Mangroves are considered as a crucial component of the world's coastal ecosystems representing an integrated environmental system to stabilize coastal lands and offer protection against storms and sea-level rise (Mukherjee et al., 2010). They alleviate devastating effects of erosion, storm surges and flooding of coastlines (Zhang et al., 2012). Moreover, The importance of coastal intertidal mangrove habitats comprises their contributions in increasing the sedimentation rate (Thampanya et al., 2006), acting as a physical and biogeochemical barrier for contaminants attacking coastal estuaries and other water bodies (Chowdhury et al., 2016; Qiu et al., 2011) and helping in the accumulation and partitioning of trace elements in the rhizosphere (Zhou et al., 2011). Considered as woody plants mangroves inhabit intertidal zones with high salinity (Shan et al., 2008; Parida and Jha, 2010) and can tolerate a wide range of salinities under natural conditions (Suàrez et al., 1998). Also mangroves have wide ecological amplitude ranging from tropical to temperate regions across all continents and dominate large extents of shorelines, estuaries and islands in tropical and subtropical regions worldwide forming biologically important and productive transitional coastal ecosystems (Alongi, 2002; Soares et al., 2012; Wang et al., 2013). As mangroves are considered as assemblages of trees and shrubs, they sustain both ecological and economical services in ecosystems (Alongi, 2009), and playing an important role in both biogeochemical cycles and economic activities (Thua and Populus, 2006). About 80 species of true mangrove trees/shrubs are recognised, from which around 50-60 species make a significant contribution to the structure of mangrove forests. Species diversity is much higher

e-mail: aminsameh2012@gmail.com 
in the Southeast Asian Region, where approximately two-thirds of all species are found, while approximately 15 species exist in Africa and 10 species in the Americas (FAO, 2007). It is known that more than $90 \%$ of the world's mangroves are located in developing countries (Duke et al., 2007). The trees of several genera are economically valuable for timber or fuelwood, especially Rhizophora species. Since, more than one-third of the global human population lives along coastal areas, their long-term sustainability depends on the coastal ecosystems (Barbier et al., 2008). However, human activities and interventions within and near these mangrove areas have led to their degradation and the resources therein (Alongi, 2002; FAO, 2007). Large areas of mangrove have been converted into fishponds (Ellison, 2008), salt ponds, agriculture and coastal projects (Ong et al., 1995). Over the globe, due to disturbance of species distribution, mangroves have been disappearing at an alarming rate worldwide by an annual rate of $1-2 \%$ (FAO, 2007; Lewis, 2009). The loss of mangrove forests has increased from regions of highly anticipated rise in global temperature (Koch et al., 2015). Thus mangroves may vanish if the destruction of their ecosystems continues repeatedly (Duke et al., 2007).

Mangrove plant cover are found along some coastlines of the arid Arabian Peninsula (Balakrishnan, 2012). They are present in the form of fragmented stands in many tidal areas on the Red Sea and the Arabian Gulf coast, south of latitude $26^{\circ}$ north. They consist mainly of Avicennia marina trees. On the coast of the Red Sea, Avicennia marina is accompanied by a few of Rhizophora mucronata, however it is very rare in Saudi Arabian Gulf (Thua and Populus, 2006). Mangrove ecosystems are limited along Arabian Gulf and they are confined to Dammam area (Taraut Bay), with well-developed communities consisting of Avicennia marina. The inter-tidal mangrove environment of Eastern Region of Arabian Coast is very important as it supports the local fishing activities, nursery grounds for many fish, crustaceans and shellfish species, as well as being central for ecotourism activities. Also due to the consistently diminishing erosion resistance, the extent of mangrove plant cover along the Saudi Arabian Gulf has been considerably decreased. Moreover, in the Arabian Gulf area mangrove ecosystems have been principally affected by the large oil spills from the Gulf War (Saenger,1993). It is also threatened by the expansion of human settlements, the boom in commercial aquaculture, the impact of tidal waves and storm surges. Noticeably, in Taraut Bay it has exhibited drastic reduction due to major stressors including landfilling, dredging, coastal development, solid and liquid waste disposal (Danish, 2010).

Fortunately, members of the genus Avicennia are dominant within higher latitude forests and documentary they have expanded their range in recent decades along three continents (Saintilan $e t$ al., 2014). It is not too late to renew the loss in productivity of the mangrove areas, and their plant cover can be rehabilitated and maintained (Palis, 1998). The present study is conducted to frame the human impact assessing the physico-chemical parameters on mangrove vegetation in Dammam area (Fig.1), especially at Taraut Island. The main objective will be extended to estimate the reduction of mangrove ratio during the last decades and to throw a highlight spot on mangrove future over the next few decades.

\section{Materials and Methods}

\section{Study Site:}

Satellite, Google Earth, pictures, images and geographic information systems provide collectively useful tools to detect and map the temporal variation in mangroves coverage (Riaza, et al. 1998; Long and Skewes, 1996; Verstraete et al. 2008). For this purpose the temporal changes in the geographic distribution of mangroves along the Arabian Gulf Coast at Dammam Region have been studied by conducting the historical Landsat Multispectral Scanner (MSS) and Landsat Enhanced Thematic Mapper (ETM) adopted by Khan and Kumar (2009) (Figs 2-4). New changes in these maps and images were made in the present work through field studies (Fig. 1). 


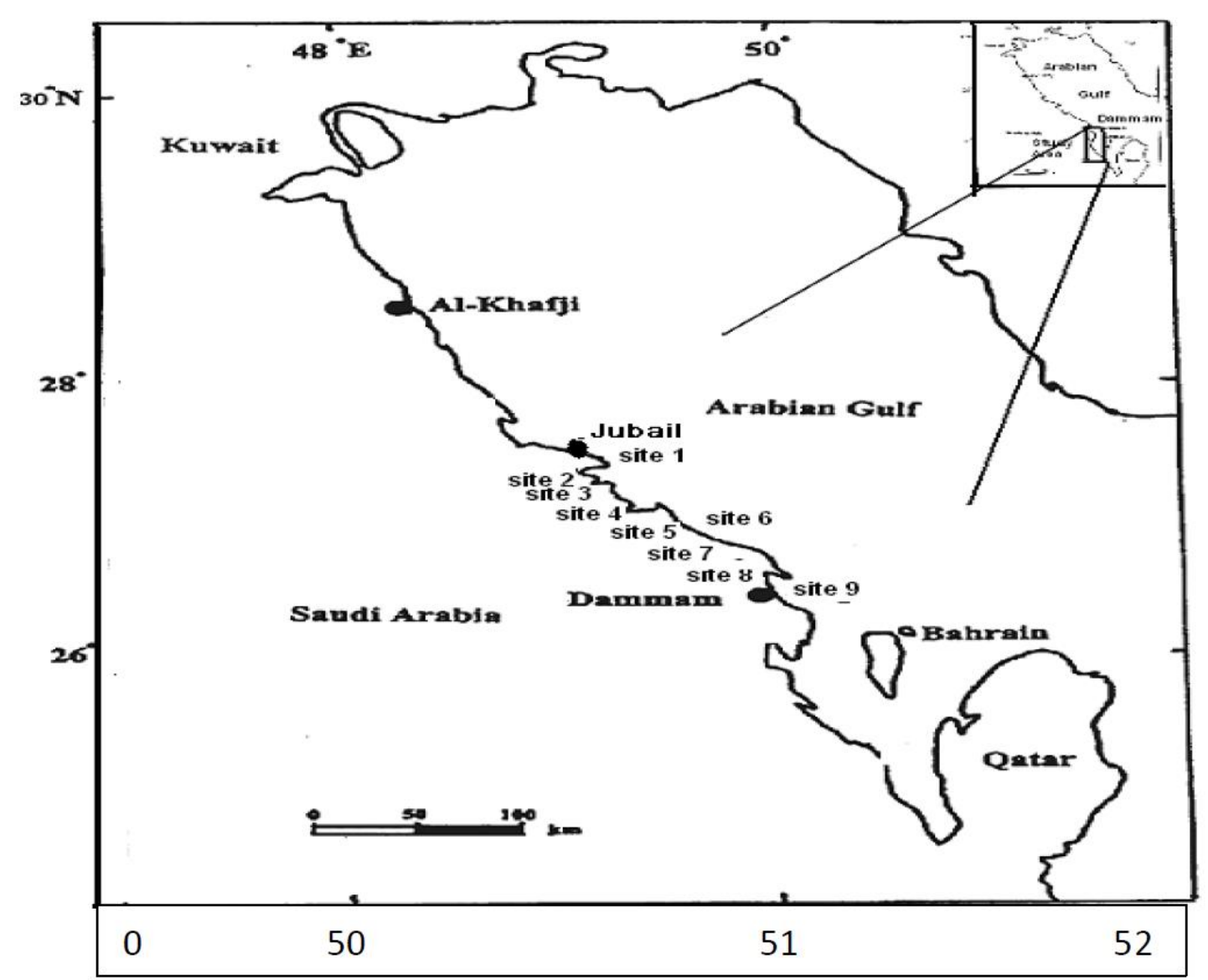

Fig. (1): Map of the sampling sites at the Eastern Region of Arabian Gulf, KSA.

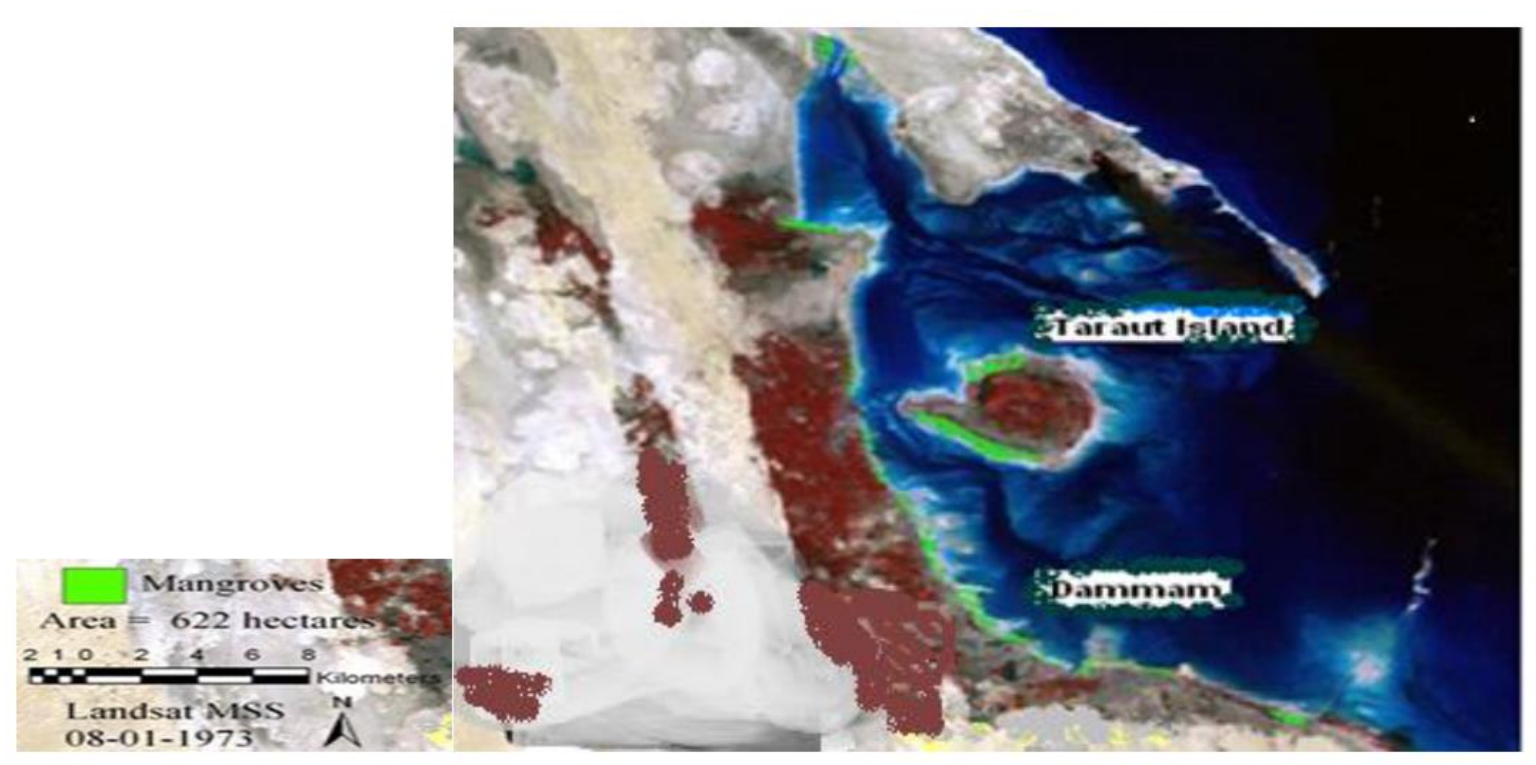

Fig. (2): Satellite image of mangroves area (622 ha) in 1973. 

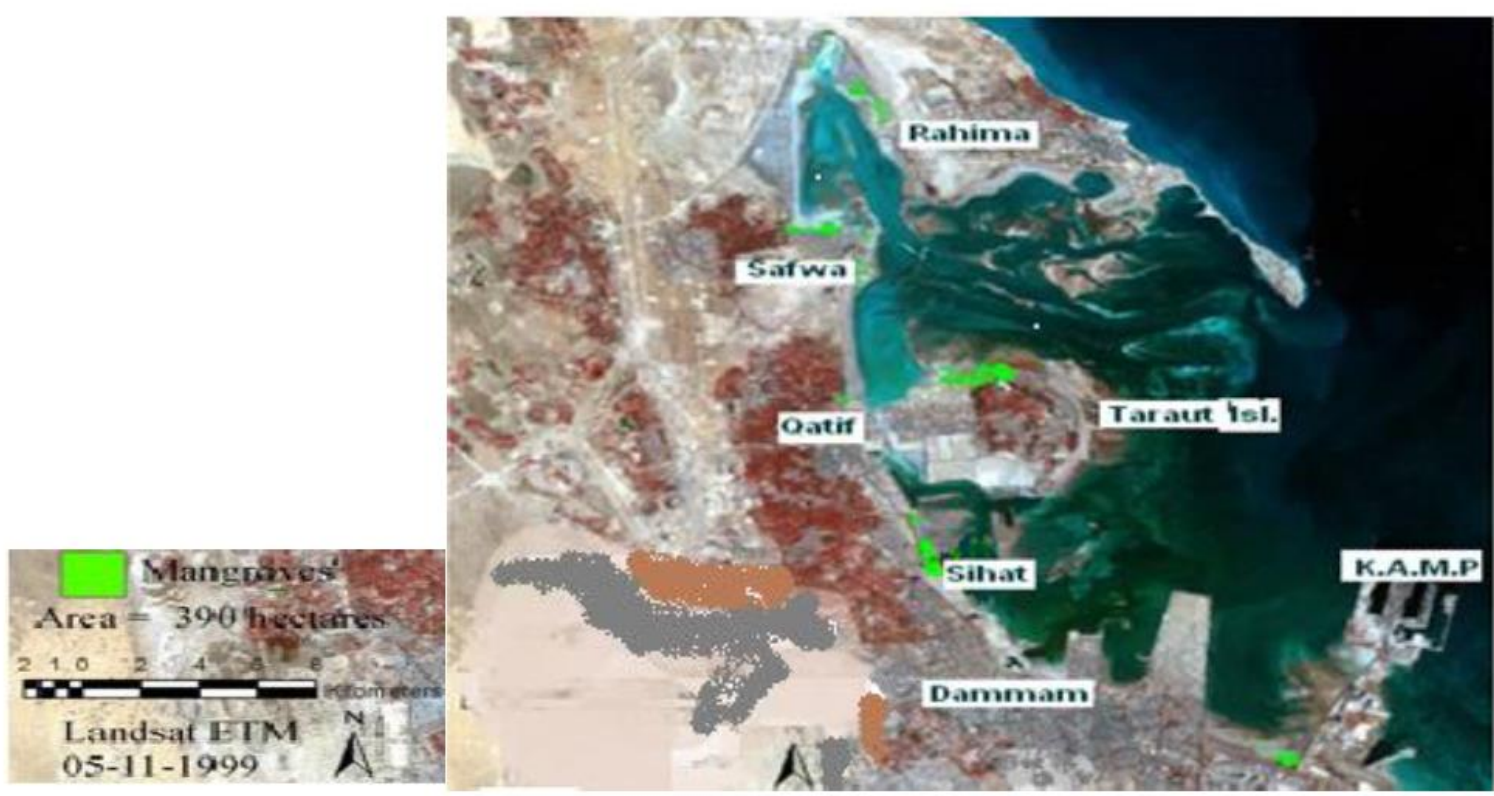

Fig. (3): Satellite image of mangroves area (482 ha) in 1999. After (Khan and Kumar, 2009).

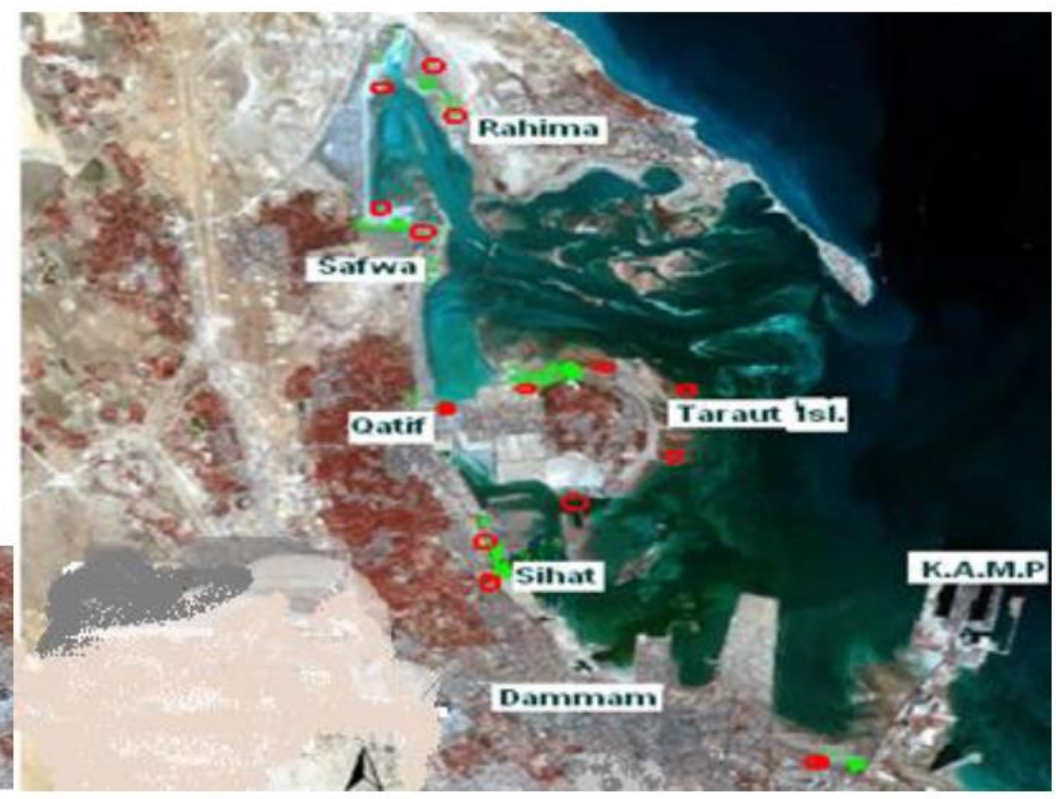

Fig. (4): Satellite image of mangroves area (green color), and red circles are threatened areas endangering their survival during the present decade.

Field Measurements:

a)Vegetation:

Nine locations were selected across mangrove forest. Three transects were outlined and laid out in such a way to represent the variations of mangrove trees at each site. The abundance and growth parameters (the plant height, size index, leaf area, number of main and lateral branches, number and height of aerial roots and number of seedlings $/ \mathrm{m}^{2}$ ) of mangrove were measured at each site to evaluate the growth rate.

B) Water and Sediment Sampling And Analysis: 
Across a distance of about 5 to $10 \mathrm{~km}$ along the Arabia Gulf coast of Eastern Region, KSA (Fig. 1 ), monthly visits were arranged to the studied area throughout the period from January 2013 to January 2016 collecting water and sediment samples from the same experimental locations. Surface water and sediment were gathered randomly from a depth of $0-15 \mathrm{~cm}$. Surface water and sediments were analyzed to determine both physical and chemical characteristics. The concentration in water and sediment are expressed in $\mathrm{mg} / \mathrm{L}$ and in $\mathrm{mg} / \mathrm{kg}$ dry weight respectively.

The experimental results were extended to measure $\mathrm{pH}$ and turbidity of the water in-situ (in duplicate); using the electrometric method for $\mathrm{pH}$ and the Nephelometric method for turbidity as per standard methods (APHA, AWWA and WEF 2005). The biological oxygen demand (BOD) was determined following the method described in the APHA, AWWA and WPCF (1985) while TDS is measured according to standard method of APHA (2005).

Consequently, the collected sediment samples were air dried and then crushed for further analysis. A $5 \mathrm{~g}$ of field-moist soil was thoroughly mixed with $25 \mathrm{ml}$ distilled water in polyethylene centrifuge tubes and placed on a spinning wheel for $2 \mathrm{~h}$. on termination of the shaking the soil-water slurry was left to settle for $10 \mathrm{~min}$ and its $\mathrm{pH}$ was measured using an Orion 290A pH meter (Birch et al., 2011). Also, the sediment organic matter (TOC) was determined according to Walkley and Black method (1934).

Phosphorus concentration was estimated using a colorimetric assay as described in Reef $\mathcal{E}$ Lovelock (2014). Also the method of Flindt and Lillebo (2005) was used to quantify the Nitrogen content in the soil samples. It has to be noted that this method is a modification of the standard Kjeldhal-N method. Furthermore, soil samples were analyzed for Sulphates estimation according to the method adopted by Jackson (1967) by titration against $\mathrm{BaCl}_{2}$ in presence of tetrahydroxy-quinone as indicator.

\section{C) Human Impact Assessment:}

As Tarout Island is predominantly considered as one of the most ancient sites that were inhabited by humans, moreover, the Island had a significant role in trading purposes in the entire Arabian-Gulf region (https://en.wikipedia.org/wiki/Tarout_Island). Since the island has a legacy of severe human-induced environmental degradation over its existence, therefore the effect of landfilling, dredging, coastal development and solid waste disposal are presently studied regarding mangrove ecosystem. Therefore, it is mandatory in this present work to quantify anthropogenic disturbance and fouling in terms of degrees $(0,-1,-2)$ on the biodiversity of the sites under investigation.

\section{Statistical Analysis}

Analyses of variance (ANOVA) for the water, sediment and mangrove abundance (one-way and two-ways) were carried out. The same analyses was done for mangroves biodiversity. This analysis showed a strong significant difference for both one- way (sites) and two-ways (sites and parameters), $\mathrm{P}<0.05: 0.006$.

\section{Results and Discussion}

Water and Sediment Analysis:

The recorded data in Tables (1 and 2), clarifies the values of physico-chemical characteristics of water and soil at the investigated sites of Arabian Gulf coast in Saudi Arabia, respectively. The average measured values of $\mathrm{pH}$ are within the alkaline range that enables and supports biological life in agreement with previous studies (GreenTech Consultants 2009; Harris and Vinobaba 2012). Mangroves are well known for their halophytic characteristics (Gong and Ong, 1990), which allow them to survive in high salinity through certain mechanisms of salt tolerance (Wakushima et al., 1994). However, total dissolved solids (TDS) exhibits normal concentrations with relatively steady rates in most samples. Meanwhile, site V showed the highest total suspended solids (TSS) magnitude (5.4 $\mathrm{mg} / \mathrm{L})$ followed by site VI. The rest of specimens showed a descending trend. Several studies have reported that Avicennia marina is largely predominant in high saline environments, where salinity is 
154 shown to be $\geq 25 \mathrm{ppt}$ during most of the months of the year (Karunathilake 2003; Jayatissa et al. 2008). 155 Moreover, Avicennia marina is a facultative halophyte having various adaptations for hypersaline 156 environments (Shete et al. 2007; Jayakody et al. 2008).

157 Table (1): Some physico-chemical features of water supporting the growth of mangroves at inspected 158 sites of Arabian Gulf Coast, Eastern Region, KSA.

\begin{tabular}{|c|c|c|c|c|c|c|c|}
\hline Parameter & $\mathrm{pH}$ & $\begin{array}{l}\text { Turbidity } \\
\text { (NTU) }\end{array}$ & $\begin{array}{c}\text { Total } \\
\text { Dissolved } \\
\text { Solids } \\
\text { (TDS) } \\
(\mathrm{mg} / \mathrm{L})\end{array}$ & $\begin{array}{c}\text { Total } \\
\text { Suspended } \\
\text { Solids } \\
\text { (TSS) } \\
(\mathrm{mg} / \mathrm{L})\end{array}$ & $\begin{array}{c}\text { Total } \\
\text { Phosphorus } \\
\text { (TP) } \\
(\mathrm{mg} / \mathrm{L})\end{array}$ & $\begin{array}{c}\text { Total } \\
\text { Nitrogen } \\
(\mathrm{TN}) \\
(\mathrm{mg} / \mathrm{L})\end{array}$ & $\begin{array}{c}\text { Biochemical } \\
\text { Oxygen } \\
\text { Demand } \\
\text { (BOD) } \\
(\mathrm{mg} / \mathrm{L})\end{array}$ \\
\hline $\mathrm{I}$ & $8.1 \pm 0.5$ & $5.8 \pm 0.9$ & $44500 \pm 4000$ & $1.8 \pm 0.4$ & $2.4 \pm 0.4$ & $1.4 \pm 0.2$ & $7.9 \pm 0.4$ \\
\hline II & $8.1 \pm 0.4$ & $6.1 \pm 0.8$ & $41300 \pm 2400$ & $1.5 \pm 1.1$ & $2.1 \pm 0.2$ & $1.3 \pm 0.3$ & $8.8 \pm 1.1$ \\
\hline III & $8.1 \pm 0.4$ & $12.2 \pm 1.2$ & $41500 \pm 3000$ & $1.8 \pm 0.5$ & $2.1 \pm 0.3$ & $1.4 \pm 0.2$ & $9.8 \pm 2.1$ \\
\hline IV & $8.0 \pm 0.5$ & $8.2 \pm 1.8$ & $42000 \pm 1700$ & $1.9 \pm 1.1$ & $3.1 \pm 0.8$ & $1.6 \pm 0.2$ & $9.6 \pm 1.6$ \\
\hline V & $7.9 \pm 0.5$ & $8.2 \pm 1.1$ & $36500 \pm 3100$ & $5.4 \pm 2.7$ & $5.1 \pm 1.1$ & $6.5 \pm 0.9$ & $18.8 \pm 3.1$ \\
\hline VI & $8.0 \pm 0.3$ & $7.2 \pm 1.3$ & $37800 \pm 2000$ & $3.1 \pm 0.9$ & $3.9 \pm 0.7$ & $3.1 \pm 0.6$ & $10.8 \pm 1.3$ \\
\hline VII & $8.1 \pm 0.4$ & $5.5 \pm 0.7$ & $38000 \pm 3000$ & $1.6 \pm 0.9$ & $3.4 \pm 0.9$ & $2.2 \pm 0.4$ & $9.2 \pm 2.4$ \\
\hline VIII & $8.2 \pm 0.5$ & $4.5 \pm 0.6$ & $40200 \pm 2200$ & $2.2 \pm 1.1$ & $2.9 \pm 0.6$ & $2.1 \pm 0.3$ & $8.9 \pm 1.1$ \\
\hline IX & $8.2 \pm 1.1$ & $5.2 \pm 1.1$ & $40500 \pm 2400$ & $2.1 \pm 1.1$ & $2.9 \pm 0.7$ & $2.3 \pm 0.2$ & $8.8 \pm 2.3$ \\
\hline
\end{tabular}

(mean values $\pm \mathrm{SE})$

160 Table (2): Some physico-chemical features of sediment supporting the growth of mangroves at 161 inspected sites of Arabian Gulf Coast, Eastern Region, KSA.

\begin{tabular}{|c|c|c|c|c|c|c|}
\hline $\begin{array}{c}\text { Parameter } \\
\text { Sites }\end{array}$ & $\mathrm{pH}$ & $\begin{array}{c}\text { Total } \\
\text { Dissolved } \\
\text { Solids } \\
\text { (TDS) } \\
\text { (mg/kg) }\end{array}$ & $\begin{array}{l}\text { Total } \\
\text { Organic } \\
\text { Carbon } \\
\text { (TOC) } \\
(\mathrm{mg} / \mathrm{kg})\end{array}$ & $\begin{array}{c}\text { Total } \\
\text { Phosphoru } \\
\text { s } \\
\text { (TP) } \\
\text { (mg/kg) }\end{array}$ & $\begin{array}{c}\text { Total } \\
\text { Nitrogen } \\
\text { (TN) } \\
(\mathrm{mg} / \mathrm{kg})\end{array}$ & $\begin{array}{l}\text { Sulfate } \\
(\mathrm{mg} / \mathrm{kg})\end{array}$ \\
\hline I & $8.0 \pm 0.3$ & $39500 \pm 3000$ & $4.8 \pm 0.6$ & $2.2 \pm 0.1$ & $1.9 \pm 0.3$ & $3500 \pm 450$ \\
\hline II & $8.0 \pm 0.2$ & $38700 \pm 2200$ & $4.5 \pm 0.7$ & $2.1 \pm 0.1$ & $1.8 \pm 0.3$ & $3000 \pm 400$ \\
\hline III & $7.9 \pm 0.3$ & $37500 \pm 2500$ & $5.8 \pm 0.5$ & $2.2 \pm 0.2$ & $1.9 \pm 0.4$ & $2400 \pm 260$ \\
\hline IV & $7.9 \pm 0.4$ & $37000 \pm 2000$ & $7.9 \pm 1.1$ & $3.3 \pm 0.6$ & $2.3 \pm 0.4$ & $2500 \pm 200$ \\
\hline $\mathrm{V}$ & $7.7 \pm 0.3$ & $33500 \pm 2400$ & $11.4 \pm 2.7$ & $5.4 \pm 0.9$ & $5.9 \pm 0.7$ & $1600 \pm 200$ \\
\hline VI & $8.0 \pm 0.4$ & $34800 \pm 2100$ & $7.1 \pm 1.9$ & $3.6 \pm 0.4$ & $3.2 \pm 0.4$ & $1800 \pm 200$ \\
\hline VII & $8.0 \pm 0.3$ & $35000 \pm 2300$ & $6.6 \pm 0.9$ & $3.1 \pm 0.3$ & $2.4 \pm 0.3$ & $2100 \pm 300$ \\
\hline VIII & $8.0 \pm 0.4$ & $36200 \pm 2000$ & $5.2 \pm 1.1$ & $2.8 \pm 0.6$ & $2.6 \pm 0.4$ & $2900 \pm 400$ \\
\hline IX & $8.0 \pm 0.3$ & $36500 \pm 2500$ & $5.1 \pm 1.1$ & $2.9 \pm 0.4$ & $2.9 \pm 0.7$ & $3100 \pm 500$ \\
\hline
\end{tabular}

(mean values $\pm \mathrm{SE})$

163

164

165

166

167

168

169

170

171

As turbidity measurement could be employed to provide an estimation of total dissolved solids, it has been examined and was found to have the highest values in site III (12.2 NTU) followed by sites IV and V when compared to other locations. Since Phytoplankton, sediments from erosion and resuspended sediments arising from agitation of the bottom sediments comprising some detritus particles are light they remain suspended in water. Table (3) exhibits a list of anthropogenic actions including waste discharge, urban runoff, and fishing yielding to an aggravated problem. Similar deductions were demonstrated by Guhathakurta and Kaviraj, (2004).

Regarding the total phosphorus and nitrogen, biochemical oxygen demand BOD and total organic carbon TOC, site V followed by site IV recorded the maximum values when compared to 
172

173

174

175

176

177

178

179

180

181

182

183

184

185

186

187

188

189

190

191

192

193

194

195

196

197 other sites. Site I showed the lowest concentrations. The largest values of these parameters in sediment could be referred to the increased concentration in water (Zyadah, 2011). Sulfur is an essential chemical component which is used as sulfate $\left(\mathrm{SO}_{4}{ }^{2-}\right)$ for the structure of the plants and different biological processes (Hopkins and Hüner, 2004). For all the investigated sites, the amount of sulfates $\left(\mathrm{SO}_{4}{ }^{2-}\right)$ exceeds $1600 \mathrm{mg} / \mathrm{kg}$, a result that is emphasized by Reddy and D'Angelo (1997) stating that the minimum value of the sulfates in the coastal area must not be less than $2 \mathrm{ppm}$. On the other hand, the allowable range of nitrogen in the soil is between $10 \mathrm{ppm}$ to $60 \mathrm{ppm}$ (Gong and Ong, 1990). Hence, nitrogen is lower than the normal range over all sites. The distribution of $P$ and $N_{2}$ are associated with organic matter. Apart from site $\mathrm{V}$, variations recorded for the sites are relatively small, and may be associated with contrasting sedimentation patterns, which is in accordance with Marinho et al. (2012).

Table (3): Anthropogenic impact on the biodiversity at the inspected sites.

\begin{tabular}{|c|c|c|c|c|c|c|c|c|c|}
\hline $\begin{array}{c}\text { Site } \\
\text { HumanImpact }\end{array}$ & $\mathbf{I}$ & II & III & IV & $\mathbf{V}$ & VI & VII & VIII & IX \\
\hline Diving \& Boat anchor & 0 & -2 & 0 & 0 & 0 & -1 & 0 & 0 & 0 \\
\hline Fishing & -2 & -2 & -1 & 0 & 0 & -1 & 0 & 0 & 0 \\
\hline Sewage drainage water & 0 & -2 & -2 & -1 & -1 & 0 & -1 & -1 & -1 \\
\hline Agricultural waste water & 0 & 0 & -1 & -2 & -1 & 0 & -1 & -1 & 0 \\
\hline Trampling & -1 & -1 & -2 & -2 & -2 & -1 & -2 & -2 & -1 \\
\hline Grazing (sheep and camels) & 0 & -1 & -1 & -1 & 0 & 0 & -1 & 0 & 0 \\
\hline
\end{tabular}

Impact degree: 0 is neutral, -1 negative impact, -2 much negative impact.

Figure (5) takes into account the human impact illustrating the quantity of waste water drained in the sites under consideration. Thus, the elevated amount of nutrients in water and sediment may be attributed to the increase of sewage and agricultural drainage water at these sites, wastes from ships and boats and in addition to the decomposition of dead plants, particularly at site $\mathrm{V}$ which could be referred to the increased levels of organic carbon. TOC levels imply that the sediments inside Mangrove forest could retain organic matter. Additionally, the decayed litter released nutrients into sediments, which would contribute to the increase of organic matter in the sediments. As a consequence, Mangrove plants improve the sediment fertility and promote the physicochemical properties of the intertidal habitat, which would influence the biogeochemical processes of other elements in the sediment (Li et al., 2016). During Mangrove succession, the diversity and biomass of the plant community increase; as a consequence, the matured Mangrove community provides an abundance of sediment biogenic matter, such as SOM, TC, TN, TP and TK (Chen et al., 2016). 


\section{Waste water drains to Arabian Gulf}

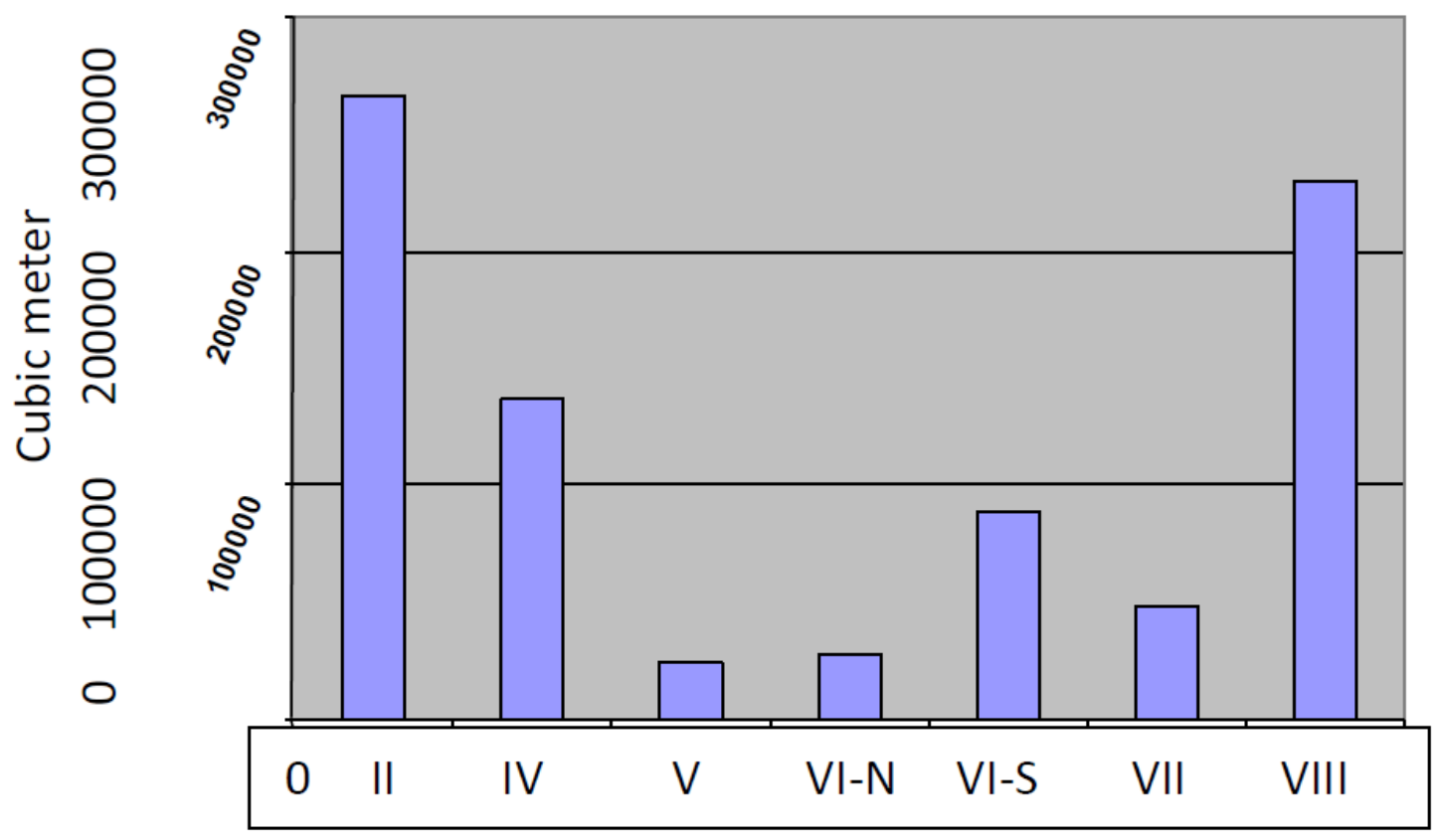

Fig. (5): The quantity of waste water drained into the studied sites.

Plasticity of mangrove seedlings in environmental conditions is common but has mainly been related to other abiotic factors such as light or water availability (Sultan 2000). Owing to the richness of some investigated locations with nutrients, hence the high abundance and growth " plant height, size, number of main and lateral branches" of Avicinia marina at sites V, VII and VIII were noticed as compared to the other sites, while the lowest density was obtained at sites I, IV and IX. Human impact was recorded at all sites, where urban development was clear in sites IV, V, VI and VIII. 


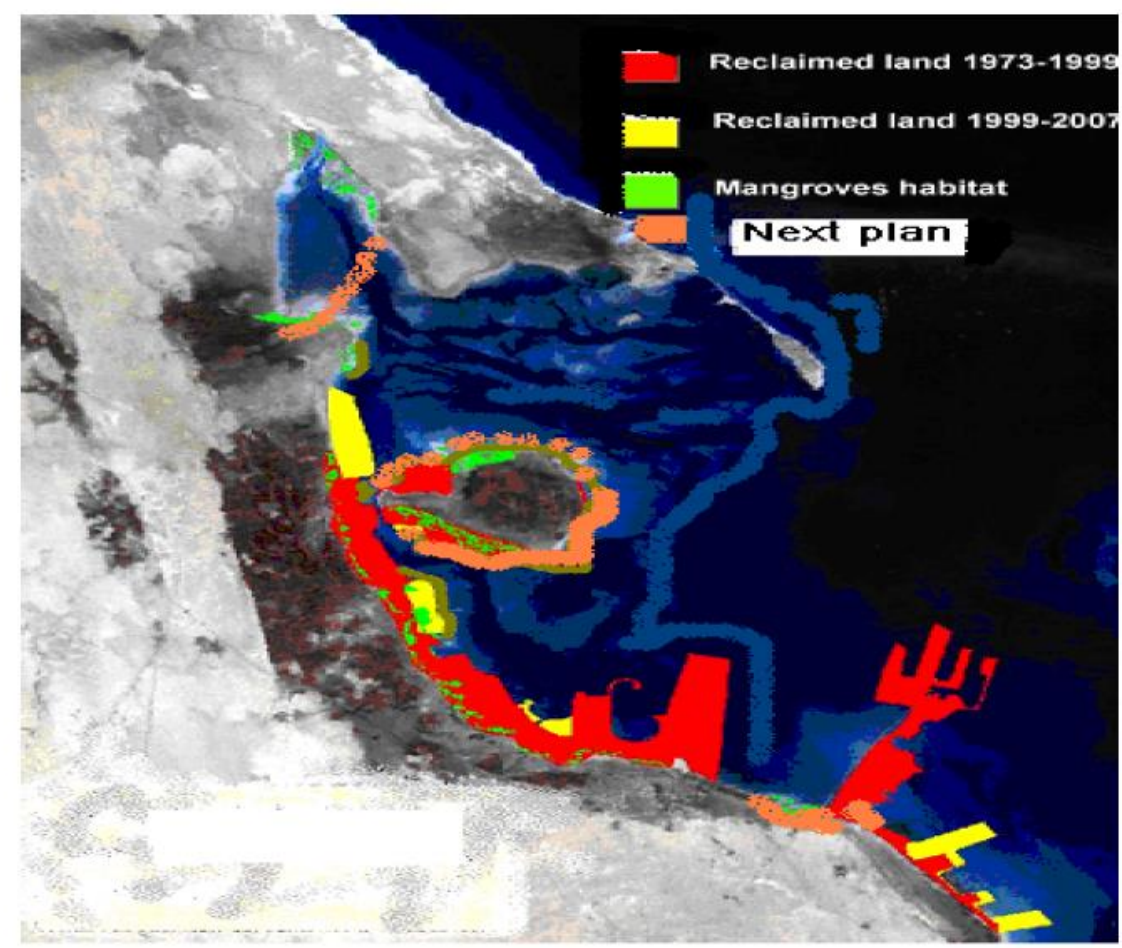

Reclaimed land from 1973 -1999 Mangroves habitats
Reclaimed land from 1999-2007

\section{Next Plan}

Fig. (6): Landfilled area in Taraut Island and Dammam, during last 40 years.

Significant changes have occurred in Saudi Arabia Gulf coast over the last three decades. Figs. 2 and 3 showed the Satellite image of mangroves area (622 ha) in 1973 which is reduced to an area of 482 ha in 1999 (Khan and Kumar, 2009). Many aspects of development were recorded in Dammam and Qatif regions that negatively affect the Mangrove plant cover. Fig.(4) shows the last urban disturbance on mangrove which results in plant cover reduction from 482 ha to 390 ha during 1999 to 2009. In a close observation, Fig.(6) shows the landfilling in the studied area during the last four decades. There is a negative impact on the mangrove occurrence as a result of the coastal development that include dredging, filling, and other activities like oil pollution and drainage water (Fig. 5).

In conclusion, the current work is an attempt to demonstrate threats and difficulties that are facing mangroves in their natural habitats. Also, this work outlines the severity of ecological implications that disturb the coastal ecotone where mangrove thrives. In addition, the research emphasizes the ability of Avecinnea marina to overcome contamination and human disturbances in the ambient environment. The economic, social, and environmental value of Mangrove must be assessed for awareness rising of local communities. However, greater losses in fringe Mangroves and an increased area of basin mangroves can be related to sea-level rise and increased mean air temperatures that in turn related to current climate change (Campbell et al., 2010).Climate change is a futuristic problem creating stress to the entire biosphere. The overexploitations of mangrove forest and oil pollution are considered the main destruction factors in the Arabian Gulf (Zahed et al, 2010). Wide distribution of mangrove is ascribed to its adaptation resilience. A conducted trial In Saudi Arabia, remote sensing data was used to locate suitable sites for Mangrove plantation along the Red Sea Coast (Abd-El Monsef et al., 2013).

Author Contributions: S. A. Ismail, M. Zyadah and M. S. Fouad conceived and designed the experiments. S. A. Ismail and W. Ataisan performed the experiments. S. A. Ismail, analyzed the data. S. A. Ismail, M. Fouad, W. Ataisan and M. Zyadah wrote the manuscript; S. A. Ismail and M. S. Fouad provided editorial advice. 
233

234

235 References paper.

Conflict of Interests:The authors declare that there is no conflict of interests regarding the publication of this

Abd-EI Monsef, H.; Aguib, A.; and Smith, S. (2013). Locating suitable Mangrove plantation sites along the Saudi Arabia Red Sea Coast. J. of African Earth Sciences, 83, 1-9.

Alongi, D. M. (2002). Present state and future of the world's Mangrove forests. Environ. Conserv., 29, 331-349.

Alongi, D. M. (2009). The Energetics of Mangrove Forests. Springer, Dordrecht.

APHA, (2005). Standard Methods for the Examination of Water and Wastewater. 21st ed. Washington, DC. American Public Health Association.

APHA; AWWA and WEF. (2005). Standard Methods for the Examination of Water and Wastewater, 21 st ed. Washington, DC. American Public Health Association/American Water Works Association/Water Environment Federation.

APHA; AWWA and WPCF. (1985). Standard Methods for the Examination of Water and Waste water. 16th ed. Washington DC. American Public Health Association.

Balakrishnan, P. (2012). Application of remote sensing for Mangrove mapping: a case study of AlDhakira, the State of Qatar. Journal of Earth Science and Engineering, 2, 602-612.

Barbier, E.B.; Koch, E.W., Siliman, B.R., Hacker, S.D. and Wolanski, E. (2008). Coastal ecosystembased management with nonlinear ecological functions and values. Science, 318, 321-323.

Birch, G. F.; Vanderhayden, M. and Olmos, M. (2011). The nature and distribution of metals in soils of the Sydney estuary catchment, Australia. Water Air Soil Pollut, 216, 581-604.

Campbell, J.; Taylor, M.; Stephenson, T.; Watson, R. and Whyte, F. (2010). Future climate of the Caribbean from a regional climate model. Int. J. Climatol., 31, 1866-1878.

Chen, Q.; Zhao, Q.;, Li, J.; Jian, S. and Ren, H. (2016). Mangrove succession enriches the sediment microbial community in South China. Scientific Reports 6 , 27468|DOI:10.1038/srep27468, www.nature.com/scientificreports

Chowdhury, R.; Lyubun, Y.; Favas, P. J. and Sakar, S. K. (2016). Phytoremediation potential of selected Mangrove plants for trace metal contamination in Indian Sundarban Wetland. In: 
Phytoremediation: Management of Environmental contamination, 4, 283-310 Springer. ISBN: 978-3-319-41810-0. DOI: 10.1007/978-3-319-41811-7_15.

Danish, E. Y. (2010). Ecological impact from chemicals in the Arabian Gulf due to Gulf oil spill. Water and Environment Journal, 24, 65-73. http://dx.doi.org/10.1111/j.1747$\underline{6593.2008 .00145 . x}$

Duke, N. C.; Meynecke, J.; Dittmann, S.; Ellison, A. M.; Anger, K.; Berger, U.; Cannicci, S.; Diele, K.; Ewel, K.C.; Field, C. D.; Koedam, N.; Lee, S. Y.; Marchand, C. Nordhaus, I. and Dahdouh-Guebas, F. (2007). A world without Mangroves? Science, 317, 41-42.

Ellison, A. M. (2008). Managing Mangroves with benthic biodiversity in mind: moving beyond roving banditry. Journal of Sea Research, 59, 2-15.

FAO, (2007). The World's Mangroves 1980-2005. Food and Agriculture Organization. of the United States, Rome.

Gong, W. and Ong, J. (1990). Plant biomass and nutrient flux in a managed Mangrove forest in Malaysia, Estuarine, Coastal and Shelf Science, 31, 519-530.

GreenTech Consultants. (2009). Seasonal Variation in Water Quality in Batticaloa Lagoon, including the Identification of the most likely Sources of key Pollutants Assayed and Recommendations to Improve the Future Water Quality of the Lagoon, Final Report, p. 80, Annexure 6, May2010, NEC/PO/TECS(II)/08/05, NECCDEP/GreenTech Consultants, (NECCDEP).

Guhathakurta, H. and Kaviraj, A. (2004). Effects of salinity and Mangrove detritus on desorption of metals from brackish water pond sediment and bioaccumulation in fish and shrimp. Acta Hydrochimica et Hydrobiologia, 32,411-418.

Harris, J. M. and Vinobaba, P. (2012). Seasonal influence of water quality of Batticaloa Lagoon, Sri Lanka on fish and plankton abundance. International J. of Environmental Sciences, 3,371385.

Hopkins ,W. and Hüner ,N. (2004). Introduction to Plant Physiology, vol. 355, John Wiley \& Sons, New York, NY, USA, 3rd edition. 
Jackson, M. L. (1969). Soil chemical analysis. Advanced course, Dep. of Soils, Univ. of Wisc., Madisen Wisc. U.S.A.

Jayakody, JMAL. Amarasinghe, M. D., Pahala Wattaarachchi V and de Silva KHWL. (2008). Vegetation structure and potential gross primary productivity of Mangroves at Kadolkele in Meegamuwa (Negombo) estuary, Sri Lanka. Sri Lanka J. of Aquatic Sciences, 13, 95-108.

Jayatissa L. P, Wickramasinghe, W.A.A.D.L.; Dahdouh-Guebas, F. and Huxham, M. (2008). Interspecific variations in responses of Mangrove seedlings to two contrasting salinities. International Review of Hydrobiology, 93,700-710.

Karunathilake K.M.B.C. (2003). Status of mangroves in Sri Lanka. Journal of Coastal Development 7:5-9. ISSN: 1410-5217

Khan, A. M. and Kumar, A. (2009). Impact of 'urban development' on Mangrove forests along the west coast of the Arabian Gulf, Journal Earth Science India., 2, 159- 173. ISSN: $0974-8350$.

Koch, M. S., Coronado, C., Miller, M.W., Rudnick, D. T., Stabenau, E., Halley, R. B. and Sklar, F. H. (2015). Climate change projected effects on coastal foundation communities of the Greater Everglades using a 2060 scenario: need for a new management paradigm. Environ Manag, 55, 857-875. doi:10.1007/s00267-014-0375-y

Lewis, R. R. (2009). Mangrove field of dreams: if we build it, will they come? SWS Research Brief July, 1-4.

Li, R., Chai, M. and Qiu, G. Y. (2016). Distribution, Fraction, and Ecological Assessment of Heavy Metals in Sediment-Plant System in Mangrove Forest, South China Sea. PLoS ONE 11(1): e0147308. doi:10.1371/journal.pone.0147308

Long, B. G. and Skewes, T. D. (1996). A technique for mapping Mangroves with Landsat TM satellite data and Geographic Information System. Estuarine Coastal and Shelf Science, 43, 373-381.

Marinho, C. C., Campos, E. A., Guimarães, J. R. D. and Esteves, F. A. (2012). Effect of sediment composition on methane concentration and production in the transition zone of a Mangrove (Sepetiba Bay, Rio de Janeiro, Brazil). Brazilian Journal of Biology, vol. 72, no.3 429436.http://dx.doi.org/10.1590/S1519-69842012000300003. PMid:22990811. 
Mukherjee, N., Dahdouh-Guebas, F., Kapoor, V., Arthur, R., Koedam, N., Sridhar, A. and Shanker, K. (2010). From bathymetry to bioshields: a review of post-tsunami ecological research in India and its implications for policy. Environ. Manage, 46, 329-339.

Palis, H. (1998). Guidebook on the phenology and identification of Philippine Mangrove species. ERDB, College 4031, Laguna.

Parida A. K. and Jha, B. (2010). Salt tolerance mechanisms in Mangroves: a review. Trees-Structure and Function, 24, 199-217.

Qiu, Y. W., Yu, K. F., Zhang, G. and Wang, W. X. (2011).Accumulation and partitioning of seven trace metals in Mangroves and sediment cores from three estuarine wetlands of Hainan island, China. J Hazard Mater,190, 631-638.

Reddy, K. R. and D’Angelo, E. M. (1997). Biogeochemical indicators to evaluate pollutant removal efficiency in constructed wetlands, Water Science and Technology, 35,1-10.

Reef, R. \& Lovelock, CE (2014a). Historical analysis of mangrove leaf traits throughout the $19^{\text {th }}$ and $20^{\text {th }}$ centuries reveals differential responses to increases in atmospheric $\mathrm{CO}_{2}$. Glob. Ecol. Biogeogr. 23(11):1209-1214. doi:10. 1111 /geb. 12211

Riaza, A., Martinez-Torres, M. L., Ramon-Lluch, R., Alonso, J. and Heras, P. (1998). Evolution of equatorial vegetation communities mapped using Thematic Mapper images through a geographical information system (Guinea, Equatorial Africa). International Journal of Remote Sensing, 19, 43-54.

Saenger, P. (1993). Management of Mangroves in the Kingdom of Saudi Arabia. Riyadh, Saline Water Conversion Corporation and Ministry for Agriculture and Water.

Saintilan, N., Wilson, N. C., Rogers, K., Rajkaran, A. and Krauss, K. W. (2014). Mangrove expansion and salt marsh decline at Mangrove poleward limits. Glob Change Biol, 20, 147157. doi:10. 1111/gcb.12341

Shan, L., RenChao, Z., SuiSui, D. and SuHua, S. H. I. (2008). Adaptation to salinity in Mangrove: implicationon the evolution of salt tolerance. Chinese Sci., 55, 1708-1715. 
Shete, A., Gunale, V. R. and Pandit, G. G. (2007). Bioaccumulation of Zn and Pb in Avicennia marina (Forsk.) Vierh. and Sonneratia apetala Buch. Ham. from urban areas of Mumbai (Bombay), India. Journal of Applied Science and Environmental Management, 3, 109-112.

Soares, M. L. G., Duque-Estrada, G. C., Fernandez, V. and Tognella, M. M. P.(2012). Southern limit of the Western South Atlantic Mangroves: assessment of the potential effects of global warming from a biogeographical perspective. Estuarine, Coastal and Shelf Science, 101, 4453.

Suárez, N., Sobrado, M. A. and Medina, E. (1998). Salinity effects on the leaf water relations components and ion accumulation patterns in Avicennia germinans L. seedlings. Oecologia, $114,299-304$.

Sultan, S.E. (2000). Phenotypic plasticity for plant development, function and life history. Trends in Plant Science, 5, 537-542.

Thampanya, U., Vermaat, J. E., Sinsakul, S. and Panapitukkul, N. (2006). Coastal erosion and Mangrove progradation of Southern Thailand. Estuar Coast Shelf Sci., 68, 75-85.

Thua, P. M. and Populus, J. (2006). Status and changes of Mangrove forest in Mekong Delta: (Case study in Tra Vinh, Vietnam, Estuarine and Coastal Science, 71, 98-109.

Verstraete, M. M., Brink, A. B., Scholes, R. J., Beniston, M. and Smith, M. S. (2008). Climate change and desertification: where do we stand, where should we go? Global and Planetary Change, 64, 105-110.

Wakushima, S., Kuraishi, S., and Sakurai, N. (1994). "Soil salinity and pH in Japanese Mangrove forests and growth of cultivated Mangrove plants in different soil conditions,” Journal of Plant Research, 107, 39-46.

Walkley, A. and Black, I. A. (1934). An examination of the Degtareff method for determining soil organic matter, and a proposed modification of the chromic acid titration method. Soil Sci.,37, 29-38.

Wang, Y., Qiu, Q., Xin, G., Yang, Z., Zheng, J., Ye, Z. and Li, S. (2013). Heavy metal contamination in a vulnerable Mangrove swamp in South China. Environ. Monit. Assess., 185, 5775-5787. 
369 Zahed, M. A., Ruhani, F. and Mohajeri, S. (2010). An overview of Iranian Mangrove ecosystem, northern part of the Persian Gulf and Oman Sea. EJEAFCHE, 9, 411-417.

371 Zhang, K., Liu, H., Li, Y., Xu, H., Shen, J., Rhome, J. and Smith III, T. J. (2012). The role of Mangroves in attenuating storm surges. Estuar. Coast. Shelf Sci., 102-103, 11-23.

373 Zhou, Y. W., Peng, Y. S., Li, X. L. and Chen, G. Z. (2011). Accumulation and partitioning of heavy metals in Mangrove rhizosphere sediments. Environ Earth Sci , 64, 799-807.

Zyadah, M. A. (2011). Effect of human impact and pollution on the marine biodiversity in Arabian Gulf Coast, S.A., $26^{\text {th }}$ meeting of Saudi Biological Society. 